wizji antropologicznej i teologicznej, i to w obrazie wielkiego papieża, św. Grzegorza Wielkiego. Autor studium zademonstrował dobre kompetencje w omawianiu tego zagadnienia i jednocześnie potrafił $\mathrm{z}$ pewną odpowiedzialnością podjąć dość schematyczną syntezę.

ks. Andrzej Franciszek Dziuba - Warszawa

\title{
Brian DALEY SJ, The Hope of the Early Church. A handbook of patristic Eschatology, Peabody Mass. 2003, Hendrickson Publishers, ss. XIV + 303 .
}

Czasy ostateczne, koniec wieku, a szczególnie zmierzch i początek nowego milenium, zawsze oddziaływały na umysły ludzi skierowując ich myślenie na rzeczy ostateczne, ku innemu wymiarowi, ku eschatologii. Tak było przez dwa tysiące lat istnienia Kościoła, co przejawiało się w istnieniu różnych ruchów doktrynalnych zwracających uwagę na koniec świata, na magię liczby „1000" i zjawiska związane ze zmianą daty i epoki (np. ruchy millenarystyczne). Podobne zjawisko mogliśmy obserwować w ostatnich latach $\mathrm{XX}$ wieku. Nic więc dziwnego, że problemy eschatologiczne dotyczące rzeczy ostatnich, ale także tego, z czym chrześcijanie stykali się na co dzień, czyli ze śmiercią, znajdowały odzwierciedlenie w nauczaniu Kościoła, który „pochodzący z miłości Ojca przedwiecznego, założony w czasie przez Chrystusa Odkupiciela, zjednoczony w Duchu Świętym, ma cel zbawczy i eschatologiczny, który jedynie w przyszłym świecie może być osiągnięty w pełni" (KK 40). W Ewangeliach znajdujemy liczne zapisy dotyczące ludzkiego życia, śmierci oraz eschatonu - czasu na końcu czasów. Chrystus wzywa bowiem swych uczniów, zwracając uwagę na eschatologiczne wypełnienie historii: „bądźcie gotowi, bo w chwili, której się nie domyślacie, Syn Człowieczy przyjdzie" (Mt 13, 44). Wstępując zaś do Ojca pozostawił Apostołom nakaz misyjny: „Idźcie więc i nauczajcie wszystkie narody, udzielając im chrztu w imię Ojca i Syna, i Ducha Świętego. Uczcie je zachowywać wszystko, co wam przykazałem" wraz z zapewnieniem trwałości tej misji: „Ja jestem z wami przez wszystkie dni, aż do skończenia świata” (Mt 29, 19). Apostołowie kontynuując nauczanie Mistrza z Nazaretu odnosili się do czasu kiedy „nastąpi koniec, gdy przekaże królowanie Bogu i Ojcu i gdy pokona wszelką Zwierzchność, Władzę i Moc" (1Kor 15, 24). Nie mogli więc Ojcowie i pisarze kościelni pierwszych wieków pozostać obojętnymi zarówno na zapotrzebowanie wiernych, jak i na fundament położony przez Jezusa Chrystusa i Apostołów. Wielu z pisarzy starochrześcijańskich dotykało problemów eschatologicznych: końca człowieka i świata, istnienia sądu po śmierci, piekła i nieba, paruzji Chrystusa na końcu czasów. Trzeba bylo określić owo napięcie między ,już", a ,jeszcze nie”, w którym działał Kościól, żyli ludzie i w którym rozwijała się teologia. 
W ciągu ostatnich lat brakowało systematycznego i syntetycznego wykładu eschatologii patrystycznej i rozwoju doktryny chrześcijańskiej w pierwszych wiekach. Istniały jedynie artykuły i pozycje książkowe dotyczące poszczególnych pisarzy. Podstawowe opracowania - pokryte często patyna, takie jak: L. Atzberger, Geschichte der christlichen Eschatologie innerhalb der vornicänischen Zeit z 1896 roku; G.W.H. Lampe, Early Patristic Eschatology, w: Scottish Journal of Theology Occasional Papers z 1953 roku; S. Prete, La escatologia e parenesi negli scrittori cristiani latini, Bologna 1966; H. Rondet, Fins de l'homme et fin du monde, Paris 1966 roku; A.J. Visser, A Bird's-eye View of Ancient Christian Eschatology z 1967 roku, czy wreszcie współczesne G. Filoramo L'escatologia e la retribuzione negli scritti dei Padri (dai Padri Apostolici ad Agostino d'Ippona), w: Dizionario di Spiritualità Biblio-Patristica z 1997 roku; R.A. Greer, Christian Life and Christian Hope: Raids on the Inarticulate z $2001 \mathrm{r}$. nie zawsze wyrażają aktualny stan badań oraz nie omawiają szerokich problemów eschatologii w całości. Nie dotykają one także całego okresu wczesnego Kościoła, gdyż większość kończy się na Soborze Chalcedońskim i ogranicza się tylko do tacińskiej i greckiej literatury patrologicznej. Warto także uświadomić sobie, jak to zauważa Luigi Padovese, że „rozprawy o «rzeczach ostatecznych», o ile pojawiają się w książkach dogmatycznych, znajdują się w uzupełnieniach" , co można także odnieść do literatury patrystycznej, zarówno obco- jak i polskojęzycznej ${ }^{2}$. Dlatego z ogromnym zadowoleniem trzeba przyjąć wznowienie pracy o. Brian'a E. Daley'a The Hope of the Early Church. $A$ handbook of Patristic Eschatology, której pierwsze wydanie ukazało się w Cambridge University Press w $1991 \mathrm{r}$. i w błyskawicznym tempie zniknęło z półek księgarskich. Drugiego wydania podjęło się w 2003 r. wydawnictwo Hendrickson Publishers.

${ }^{1}$ L. Padovese, Wprowadzenie do teologii patrystycznej, tłum. A. Baron, Kraków 1994, 83. Taką sytuację możemy obserwować np. w wydanych ostatnio w Polsce tłumaczeniach serii podręczników teologii dogmatycznej: Historia dogmatów, red. B. Sesboüé, Kraków 1999-2003; Podręcznik teologii dogmatycznej, red. W. Beinert, Kraków 1995-2000.

${ }^{2}$ Na przykład w wydanym w 1994 r. w Krakowie podręczniku L. Padovese, Wprowadzenie do teologii patrystycznej, kwestii eschatologii u Ojców Kościoła poświęcono jeden dziesięciostronicowy rozdział: Ojcowie i eschatologia, który jest przeglądem calej myśli eschatologicznej. W podręczniku F. Drączkowskiego Patrologia, Pelplin - Lublin 1999, występują pojedyncze wątki eschatologiczne umieszczane przy okazji omawiania poszczególnych pisarzy wczesnochrześcjjańskich, podobnie zresztą jak i w innych opracowaniach: Sz. Pieszczoch, Patrologia, Gniezno 1994; A. Zurek, Wprowadzenie do Ojców Kościoła, Tarnów 2001. Próby szerszego przedstawienia rozwoju szczególowych zagadnień eschatologicznych (millenaryzm, apokatastaza, końcowe zmartwychwstanie) podjął się H. Pietras w podręczniku: Poczq̨iki teologii Kościoła, Kraków 2000, 306-327. Doktrynę wybranych Ojców Kościola dotyczącą nieba, piekła i czyśćca ukazał Z. Kijas w serii opublikowanej przez Wydawnictwo „M” (Niebo. Dom Ojca, Kraków 2001; Czyściec. Czy jest i dla kogo?, Kraków 1999; Piekło. Oddalenie od domu Ojca, Kraków 2002). Zawsze jest to jednak tylko poboczne zainteresowanie kwestiami eschatologicznymi u Ojców Kościoła z subiektywnie dokonanym wyborem autorów i zagadnień. 
Autor Brian Daley, kapłan Towarzystwa Jezusowego, wyświęcony w 1970 r., jest historykiem teologii, który specjalizuje się w studiach nad wczesnym Kościołem, szczególnie zaś nad rozwojem doktryny chrześcijańskiej od IV do VIII wieku. Przygotował m.in. krytyczne wydanie dzieł greckiego teologa Leoncjusza z Bizancjum z VI wieku, które ukazały się w serii Corpus Christianorum. Jest autorem wielu dzieł z zakresu starożytnej chrystologii, trynitologii i eschatologii. Studiował m.in. w Oksfordzie, gdzie uzyskał doktorat w zakresie teologii (1978). Jest członkiem wielu organizacji i towarzystw patrystycznych w Stanach Zjednoczonych, gdzie mieszka i wykłada na Uniwersytecie Notre Dame w Indiana (był m.in. prezesem Północnoamerykańskiego Stowarzyszenia Patrystycznego). Jest sekretarzem Orthodox-Roman Catholic Consultation in North America i redaktorem „Traditio" oraz współpracownikiem „Journal of Early Christian Studies”. W ostatnim czasie o. Daley opublikowal zbiór wczesnopatrystycznych homilii na zaśnięcie NMP (On the Dormition of Mary: Early Patristic Homilies - 1997). Obecne pola badawcze to komentarze do Psalmów oraz przeklad wybranych dzieł Grzegorza z Nazjanzu.

Prezentowana tu praca liczy 317 stron (XIV + 303) i składa się z dwunastu merytorycznych autonomicznych części, wstępów, epilogu, przypisów, bibliografii i indeksów. Materiał zamieszczony w książce jest systematyzowany chronologicznie - jak w większości podręczników patrologicznych - oraz geograficznie, co ułatwia prześledzenie ogólnego rozwoju myśli eschatologicznej, ale jednocześnie utrudnia badanie zmian, jakie dokonywały się w rozumieniu szczególowych kwestii eschatologii.

Pierwszy rozdzial (ss. 5-19): Visions of a new day: early Semitic Christianity and Christian apocalyptic omawia eschatologiczne nadzieje $\mathrm{i}$ ich rozumienie w sektach judeochrześcijańskich, wczesnych apokryfach biblijnych, u Ojców Apostolskich, w Odach Salomona, Pasterzu Hermasa, kończąc na chrześcijańskich wspólnotach milenarystycznych w Azji Mniejszej. Rozdział drugi (ss. 2024) zatytułowany: Making history intelligible: eschatology and the apologists, przedstawia widzenie eschatologicznej nadziei w pismach apologetycznych Arystydesa z Aten, Justyna Męczennika, Tacjana, Atenagorasa z Aten i Teofila $z$ Antiochii. W rozdziale trzecim (ss. 25-32) - Regaining the light: eschatology in the Gnostic crisis (150-200) - Autor ukazuje najpierw gnostycką myśl eschatologiczną w oparciu o teksty z Nag Hammadi, aby potem ukazać polemiczną odpowiedź Ireneusza z Lyonu odnośnie rozumienia Boga, świata i zbawienia ludzi. Rozdział czwarty (ss. 33-43) - Senectus Mundi: eschatology in the West (200-250) - przedstawia rozwój zachodniej myśli eschatologicznej. W sposób szczególny zwracając uwagę na wpływ warunków i środowiska na ksztaltowanie się rozumienia eschatologicznej nadziei (u Tertuliana, Minucjusza Feliksa, Hipolita Rzymskiego, Cypriana oraz w Męczeństwie Perpetuy $i$ Felicyty) przy uwzględnieniu prześladowań, społecznej alienacji chrześcijan i religijnego współzawodniczenia. W kolejnym piątym rozdziale (ss. 44-64) - 
A school for souls: Alexandrian eschatology and its critics (185-300) - przybliza chrześcijańską nadzieję eschatologiczną u przedstawicieli Szkoły Aleksandryjskiej (Klemens Aleksandryjski, Orygenes oraz jego kontynuatorzy i krytycy). W rozdziale szóstym (ss. 65-68) - The dawn of the final conflict: Latin eschatology in the Great Persecutions (303 - 313) - o. Daley zwraca uwagę na ożywienie zainteresowania apokaliptycznymi spekulacjami i eschatologiczną nadzieja, co miało związek - jak wskazuje tytuł rozdziału - z wielkimi prześladowaniami tego okresu, analizując dzieła dwóch przedstawicieli tego okresu: Wiktoryna i Laktancjusza.

Okres kilkunastu lat po Soborze Nicejskim, zarówno na Wschodzie, jak i Zachodzie, zdominowany był przez kontrowersje wokól trynitarnej koncepcji Boga, a jednocześnie naznaczony uzyskaniem przez chrześcijan w $313 \mathrm{r}$. wolności religijnej. Wszystko to, jak zauważa Autor, nie pozostaje bez wpływu na rozumienie eschatologii. Obrazuje to siódmy rozdział (ss. 69-92) zatytułowany: Facing death in freedom: Eastern eschatology in the age of Nicaea, przytaczający pisma wschodnich pisarzy: Ojców Pustyni, pisarzy syryjskich, Euzebiusza z Cezarei, Marcelego z Ancyry, Cyryla Jerozolimskiego, Apolinarego z Laodycei, Grzegorza z Nazjanzu, Grzegorza z Nyssy, Synezjusza z Cyreny. Następnie, w rozdziale ósmym (ss. 93-104) - Redemptio Totius Corporis: Latin eschatology in the fourth century - przenosi nas autor ze Wschodu na łaciński Zachód ukazując na podstawie twórczości Firmicusa Maternusa, Hilarego z Poitiers, Zenona $z$ Werony, Ambrożego, Hieronima, rozwój lacińskiej eschatologii w IV wieku.

O ile wiek IV, omawiany w poprzednich rozdziałach, znajdował się pod wpływem nicejskiej dyskusji o wspólistotności Chrystusa z Ojcem, o tyle wiek V, omówiony w rozdziale dziewiątym (ss. 105-123) - Grace present and future: Greek eschatology on the fifth century - szybko został zdominowany dyskusjami o relacji boskości i człowieczeństwa w Chrystusie. Od przedstawienia kontekstu teologicznego epoki rozpoczyna Autor omawianie greckiej eschatologii tego okresu przedstawiając nauczanie: Jana Chryzostoma, Cyryla Aleksandryjskiego, Teodora z Mopsuestii, Teodoreta z Cyru, Hezychiusza z Jerozolimy oraz dzieła ascetyczne i apokaliptyczne.

Dziesiąty rozdzial (ss. 124-167) zatytułowany: Signs of a Church triumphant: Latin eschatology in the fifth century poświęcony został V wiekowi, czyli okresowi wspaniałego rozwoju doktryny chrześcijańskiej. Przybliża on rozumienie ostatecznej nadziei w okresie w którym szczególne znamię na eschatologicznej nadziei pozostawiły zarazy, wojny, barbarzyńcy i znajdujący wówczas wielu zwolenników „ruch millenarystyczny z przekonaniem o transformacji ówczesnego posępnego świata w świat stabilizacji i pokoju" (s. 124). To właśnie wtedy tworzą wybitni pisarze chrześcijańscy, spośród których możemy poznać eschatologiczne nauczanie: Gaudencjusza z Brescii, Maksyma z Turynu, Sulpicjusza Sewera, Hilariana, Tykoniusza, Salwiana z Marsylii, papieża 
Leona Wielkiego, twórców chrześcijańskiej poezji lacińskiej, Piotra Chryzologa, autorów dwóch dziel: Liber de promissionibus i Opus imperfectum in Matthaeum czy wreszcie Augustyna z Hippony, któremu poświęcono najwięcej uwagi w tej książce, bo aż 21 stron, co stanowi 9,6\% merytorycznej jej zawartości, gdyż jak zauważył Autor „bez wątpienia teologiem, który miał największy wpływ na rozwój łacińskiej eschatologii, jak również całej łacińskiej teologii, był Augustyn z Hippony. Jego doktryna eschatologiczna, w większości punktów, jest całkowicie tradycyjna, oparta na myśli teologicznej pochodzącej z Kościoła Wschodniego od Orygenesa i Kościoła Zachodniego od Tertuliana i Hipolita, jak również czerpiąca $z$ praktyki i pielęgnowanej nadziei ówczesnych chrześcijan afrykańskich" (s. 131).

Kolejny jedenasty rozdział (ss. 168-204), zatytułowany: Apokatastasis and apocalyptic: Eastern eschatology after Chalcedon dotyczy okresu w którym „rzeczy ostateczne pozostawały, w dużej części, marginesowym tematem, dotykanym jedynie w homiliach i dzielach ascetycznych oraz opracowywanych w tradycyjnych terminach Biblii i Wyznań Wiary" (s. 168). Byl to jednak okres szczególnego przeczucia bliskiego końca świata, a jednocześnie silnych dyskusji nad platońską teorią wieczności świata i orygenesowską koncepcją powszechnego zbawienia (apokatastasis). Wobec tych problemów musieli stanąć ówcześni pisarze kościelni. Wśród Ojców Wschodnich, którym poświęcony jest ten rozdział, o. Daley zwraca także uwagę na autorów piszących w innych językach (poza greckim) analizując: Ekumeniusza, Pseudo-Dionizego, Sewera z Antiochii, Jana z Cezarei, Leoncjusza z Bizancjum, Eneasza z Gazy, Zachariasza z Mitylene, Jana Filoponusa, Aleksandriana Kosmę, Andrzeja z Cezarei, Eustratiusza, Maksyma Wyznawcę i wreszcie Jana Damasceńskiego. W ostatnim, dwunastym rozdziale (ss. 205-215): The end of all flesh: eschatology in the sixthcentury West, o. Brian Daley omawia końcowy okres patrystyki łacińskiej, w którym „nawet jeśli eschatologia stracila wiele ze swej intelektualnej finezji, to na początku wieku siódmego, stała się centralnym zagadnieniem chrześcijaństwa" (s. 205), a wpływ na to mieli z pewnością autorzy tego okresu, których przywołuje prof. Daley: Julian Pomeriusz, Cezary z Arles, Prymazjusz i Grzegorz Wielki.

Dokonując podsumowania w epilogu (ss. 216-224): Epilogue: a common hope, o. Brian Daley zastanawia się, czy można mówić o jednej, pojedynczej nadziei wczesnego Kościoła, czy raczej o wielu nadziejach i lękach; jaka jest relacja wiary i nadziei; w jaki sposób nadzieja obecna jest w historii czlowieka i świata. Odpowiedzi na te zagadnienia są okazją do podsumowania i przypomnienia, a jednocześnie do zadania pytań i wszczęcia dyskusji o problemach i kontrowersjach, które rodzą się przy okazji zgłębiania rozwoju doktryny eschatologicznej (czas i bliskość końca świata, materialny i realny charakter zmartwychwstania, zakres eschatologicznego zbawienia - apokatastaza, możliwość zmiany przeznaczenia, kwestia czyśćca). Autor kończąc swoje rozważania 
stawia pytanie: „,czy można mówié zasadnie o jednej «nadziei wczesnego Kościoła»?" (s. 216, 223), przywołując szereg kontrowersji, niedookreśleń, pojęć i stanowisk. Odpowiada na to pytanie odnosząc się do plaszczyzny egzystencjalnej: „Jeśli ktoś szuka takiej nadziei w orzeczeniach soborowych albo w wyartykułowanym i znacznie podzielonym systemie teologicznym, odpowiedź jest jasna - nie. [...]. Prawdziwym fundamentem przyszłej chrześcijańskiej nadziei jest obecne doświadczenie chrześcijan; poczucie, że jako uczniowie Jezusa, który zmartwychwstal, uczestniczą oni w większym i bogatszym życiu, którego pełny wymiar jest niedostępny rozumowi i wyobrażeniom. [...]. Chrystus, który wypełnił postanowienie (Ojca - przyp. M.W.) w czasie, jest sam jedyną normą poprzez którą chrześcijanin ocenia historię [...]. Zmartwychwstanie Chrystusa staje się dla jego uczniów w każdym czasie, obietnicą zmartwychwstania całej ludzkości; Chrystusowe wezwanie do podjęcia Jego drogi, staje się zaproszeniem do uczestnictwa w oczyszczeniu i wzroście, które muszą poprzedzać wejście do Królestwa, które On objawia" (ss. 223-224).

$\mathrm{Z}$ pewnością ogromnym atutem podręcznika o. Daleya jest doskonała bibliografia (ss. 226-290) dotycząca w pierwszej części ogólnych pojęć eschatologicznych (Eschatologia patrystyczna w ogólności, Chrześcijańska apokaliptyka, Rzeczy ostateczne, Chrześcijańskie wypełnienie, Egzegeza biblijna, Dziedziny uzupełniające), jak i indywidualnych autorów, doprowadzona do 2002 roku. Znajdziemy w niej, w analogicznym do podziału rozdziałów systemie, wiele interesujących pozycji, które są doskonałym uzupełnieniem książki, która $\mathrm{z}$ racji swego zadania, jako podręcznik, ma w założeniu tylko nakreślenie problemów eschatologii wczesnego Kościoła. Glębsze wniknięcie w nie jest właśnie możliwe dzięki załączonej obfitej bibliografii, zawierającej pozycje bibliograficzne $w$ języku angielskim, włoskim, francuskim, niemieckim i hiszpańskim. Na jej kanwie nasuwa się jednak jedna smutna refleksja o małej znajomości w świecie polskiego środowiska patrologicznego i jego osiągnięć. Wśród wielu publikacji nie znalazła się żadna polskojęzyczna ${ }^{3}$ (co da się wytłumaczyć z pewnością nieznajomością języka polskiego przez o. Briana), ale i wśród prac obcojęzycznych nazwisk polsko brzmiących udalo mi się dojrzeć jedynie sześć. I to na przeciągu ponad stu lat - gdyż najwcześniejsza publikacja wymieniona w bibliografii pochodzi z 1896 roku.

Pomocnym uzupełnieniem części merytorycznej pracy jest też Indeks (ss. 291303), który mógłby być jednak podzielony na indeks pojęć, osób i dziel, co z pewnością ułatwiłoby wyszukiwanie i uczyniłoby go bardziej przejrzystym.

Podsumowując należy przyjąć $z$ ogromnym zadowoleniem pozycję o. Briana Daleya The Hope of the Early Church, która dzięki glębokiemu studium

${ }^{3}$ Prześledzenie polskiej bibliografii patrystycznej, zamieszczanej w „Vox Patrum”, daje w tej materii wiele do myślenia i wskazuje na nikłe zainteresowanie patrologów zagadnieniami eschatologicznymi u Ojców Kościoła. 
tematu, prostemu i dostępnemu językowi przedstawia szerokiemu gronu odbiorców (zarówno profesorom jak i studentom teologii, ale i zwykłemu czytelnikowi) studium rozwoju chrześcijańskiej eschatologii i okoliczności, które miały wpływ na jej rozwój. Szerokie potraktowanie zagadnienia, omówienie mało znanych autorów, którzy pozostawiali swój ślad w ewolucji chrześcijańskiej eschatologii, a nie skupianie się tylko na największych i uznanych pisarzach chrześcijańskich, jest kolejnym dużym walorem omawianej książki, która - jak wskazuje tytul - ukierunkowana ku nadziei, nie jest suchym tylko przedstawieniem fragmentów dziel (mogą niektórzy zarzucić małą ilość dosłownych i szerokich cytatów z dziel patrystycznych, ale wydaje się, iż ograniczona wielkościowo forma podręcznika - na co wskazuje podtytuł pracy: $A$ Handbook of Patristic Eschatology - winna dawać jedynie zarys, komentarz, skondensowane wiadomości i ogólne pojęcie, a także odnośniki do poszczególnych autorów co też czyni wielokrotnie o. Daley, a nie być zbiorem samych tylko zdań i wypowiedzi wybranych $z$ dzieł Ojców Kościoła i Pisarzy Kościelnych), ale swoistym zamyśleniem nad ostateczną - eschatologiczną istotą i rolą drugiej z cnót kardynalnych na przestrzeni pierwszych wieków chrześcijaństwa. Powinna więc być to praca $\mathrm{z}$ którą zapoznają się wszyscy zainteresowani studiami nad Nowym Testamentem i pismami Ojców Kościoła.

Pozostaje więc tytułowa nadzieja, że może już wkrótce pojawi się możliwość zapoznania z podręcznikiem o. Briana Daleya także w języku polskim, bądź też z inną pracą - wspaniale gdyby rodzimego autora - która wypełniłaby dotkliwą lukę w wydanych w Polsce pracach dotyczących eschatologii u autorów wczesnochrześcijańskich.

Ks. Marcin Wysocki - Lublin - Olsztyn

Dokumenty Soborów Powszechnych. Tekst grecki, laciński, polski, układ i opracowanie ks. Arkadiusz Baron - ks. Henryk Pietras SJ, Wydawnictwo WAM, t. 1: (325-787) Nicea I - Konstantynopol I - Efez - Chalcedon Konstantynopol II - Nicea II, ŹMT 24, Kraków 2001, ss. 400; t. 2: (8691312) Konstantynopol IV - Lateran I - Lateran II - Lateran III - Lateran IV-Lyon I - Lyon II - Vienne, ŹMT 26, Kraków 2002, ss. 680.

Na polskim rynku wydawniczym, w serii „Źródła Myśli Teologicznej”, ukazały się dwa szczególne tomy, zawierające orzeczenia pierwszych siedmiu soborów powszechnych z lat 325-787 (t. I), będących wspólnym dziedzictwem Kościoła Wschodniego i Zachodniego, oraz kolejnych ośmiu z lat 859-1312 (t. 2), uznawanych za powszechne tylko przez Kościół łaciński. O ich znaczeniu nie trzeba chyba nikogo przekonywać, bo przeciez jest to oficjalna nauka Kościoła, wypracowana przeważnie z wielkim trudem, dokumentująca rozwój 